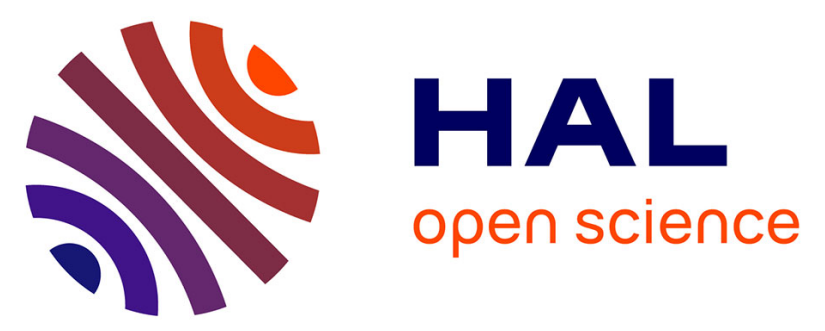

\title{
Radices et plantationes theologicae facultatis hic Parisius The Biblical Principia of Pierre Leduc and Henri le Boulangier and the Victorine Tradition during the Great Schism
}

Chris Schabel

\section{To cite this version:}

Chris Schabel. Radices et plantationes theologicae facultatis hic Parisius The Biblical Principia of Pierre Leduc and Henri le Boulangier and the Victorine Tradition during the Great Schism. Dominique Poirel,; MArcin Jan Janecki; Wanda Bajor; Michael Buraczewski. Omnium expetendorum prima et sapientia. Studies on victorine thought and influence, Brepols, 2022, 978-2-503-59650-1. hal03522269

\section{HAL Id: hal-03522269 \\ https://hal.science/hal-03522269}

Submitted on 12 Jan 2022

HAL is a multi-disciplinary open access archive for the deposit and dissemination of scientific research documents, whether they are published or not. The documents may come from teaching and research institutions in France or abroad, or from public or private research centers.
L'archive ouverte pluridisciplinaire HAL, est destinée au dépôt et à la diffusion de documents scientifiques de niveau recherche, publiés ou non, émanant des établissements d'enseignement et de recherche français ou étrangers, des laboratoires publics ou privés. 


\title{
Radices et plantationes theologicae facultatis hic Parisius \\ The Biblical Principia of Pierre Leduc and Henri le Boulangier and the \\ Victorine Tradition during the Great Schism
}

\author{
Chris Schabel*
}

The Faculty of Theology at the medieval University of Paris was dominated by secular theologians, friars from the four main mendicant orders, and Cistercian monks, followed at a distance by Benedictines and Cluniacs. Yet handfuls of canons regular from the Austin and Premonstratensian Canons and from Saint-Victor, the Val-desÉcoliers, Sainte-Genéviève, and Mont-Saint-Éloi, as well as some Servite and Trinitarian friars and assorted other regulars, were made masters of theology at the university $^{1}$. Few academic writings survive for most of these smaller groups ${ }^{2}$, which is hardly a surprise, except that one might expect more from the Victorines, who had risen to such heights in the twelfth and early thirteenth centuries that they could be labelled «the roots and shoots of the Faculty of Theology here at Paris ${ }^{3} »$.

The great Abbey of Saint-Victor thus continued to participate in the intellectual life of Paris after the city's schools evolved into the university, in which a Victorine chair of theology was established in 1237, around the time the theology curriculum was developing to include bachelor lectures on the Sentences and magisterial quodlibetal debates ${ }^{4}$. In the thirteenth century the Victorines were content with outsiders as masters,

\footnotetext{
* This paper was written under the aegis of the ERC consolidator project DEBATE, 771589. I thank Monica Brînzei, William Duba, and Dominique Poirel for their comments and assistance.

${ }^{1}$ See the lists of Parisian licentiates in theology according to religious order for the period 1373-1500 in Thomas Sullivan, Parisian Licentiates in Theology, A.D. 1373-1500. A Biographical Register. Vol. 1: The Religious Orders, Leyde, 2004 (Education and Society in the Middle Ages and Renaissance, 18), p. 385-400, as well as Vol. 2: The Secular Clergy, Leyde, 2011 (Education and Society in the Middle Ages and Renaissance, 37).

2 See for example Thomas Sullivan, «The Quodlibeta of the Canons Regular and the Monks », in Theological Quodlibeta in the Middle Ages. The Fourteenth Century, ed. Chris Schabel, Leyde, 2007 (Brill's Companions to the Christian Tradition, 7), p. 359-400. I am currently working on a study of the Sentences questions of the Servite Lorenzo Opimo of Bologna, Paris 1370-1371, the unique surviving example from that order.

3 Petrus Ducis, Principium IV in Sententias, ed. Chris Schabel, The Victorine Pierre Leduc's Collationes, Sermo finalis, and Principia on the Sentences, Paris 1382-1383, in Archives d'Histoire Doctrinale et Littéraire du Moyen Age, t. 87, 2020, p. 237-334, at p. 334.28-29: "Hugo, Richardus, et Adam, doctores huius scholar, qui fuerunt radices et plantationes theologicae facultatis hic Parisius ».

${ }^{4}$ Chartularium Universitatis Parisiensis. Tom. I, ab anno MCC usque ad annum MCCLXXXVI, ed. Heinrich DENIFLE, with Émile CHATELAIN, Paris, 1889, p. 159, no. 111 (letter of Pope Gregory IX, 26 January 1237); Marshall E. CROSSNOE, Victorine Education, 1306-1419, in Medieval Prosopography, t.
} 
but in the fourteenth century we have a series of Victorine regent masters, or at least likely candidates, covering practically the entire period of the Avignon papacy and the Great Schism ${ }^{5}$ :

Jean de Saint-Victor, perhaps regent master just prior to Gérard, active early 1310 s

Gérard de Saint-Victor, regency probably began in 1305-1306 (†1317)

Aubert de Mailley, prior and then abbot from 1 December $1329(\dagger 1345)$

Guillaume de Saint-Lô, Aubert's successor as abbot in 1345 (†1349)

Nicolas Soloe, regent master by 1364-1365 and still active in 1378-1379

Pierre Leduc, abbot from 1383, regency probably began in 1386-1387 (†1400)

Nicolas de Morencourt, held positions as prior in order from 1388 to 1414

Henri le Boulangier, regency probably began in 1409-1410 (†1419)

Nevertheless, there are no biblical or Sentences commentaries ascribed to any Victorines active at Paris after 1237 in the great repertoria of Friedrich Stegmüller ${ }^{6}$, and no true sets of quodlibetal or ordinary questions either. There is a sizeable question on the nature of theology long known to have been ascribed to Gérard de Saint-Victor in Amiens, Bibliothèque municipale 234, which turns out to pertain to the Prologue on the Sentences and, together with the preceding principium or sermon, constitutes the start of Gérard's Lectura on Lombard from around $1300^{7}$. Other than that, just about all we had

22, 2001, p. 165-180; IDEM, « 'Devout, Learned, and Virtuous': The History and Histories of the Order of Saint Victor », in A Companion to the Abbey of Saint Victor at Paris, ed. Hugh FeISS and Juliet MousSEAU, Leyde, 2018 (Brill's Companions to the Christian Tradition, 79), p. 1-53.

${ }^{5}$ See mainly Crossnoe, Victorine Education, p. 168-177. It should be noted that most mendicants, monks, and canons regular among the masters before 1373 are not listed as such in any university (or even papal) sources, so the fact that some of the Victorine masters are only identified in Victorine sources need not worry us, despite Crossnoe's concern (p. 177), especially since these Victorines had posts as prior and/or abbot of the abbey itself and did not require additional patronage. Nicolas de Morencourt is a problem: already a student in theology at Paris in 1385 at the age of around 27 (Chartularium Universitatis Parisiensis. Tom. III, ab anno MCCCL usque ad annum MCCCLXXXXIIII, ed. Heinrich DENIFLE, with Émile Chatelain, Paris, 1894, p. 389), normally he would have become master by ca. 1395, but he is not listed in the rather complete catalogues of those licensed after 1373. Perhaps he incepted elsewhere, or by papal fiat, or there is an error in the list?

${ }^{6}$ Friedrich STEGMÜLLER, Repertorium commentatiorum in Sententias Petri Lombardi, t. 1, Würzburg, 1947; IDEM, Repertorium biblicum medii aevi, t. 2-5, Madrid, 1950-1966.

${ }^{7}$ Dominique PoIREL, L'école de Saint-Victor au Moyen Âge: bilan d'un demi-siècle historiographique, in Bibliothèque de l'Ecole des Chartes, t. 156, 1998, p. 187-207, at p. 205, suggested that it was from Gérard's lost Sentences commentary; William J. CouRTENAY, Gerard of St. Victor and Amiens 234, in Bulletin de philosophie médiévale, t. 51, 2009, p. 55-62, and, published after a long delay, Marshall CRossnoe, «The Philosophical Questions of Gerard of Saint-Victor », in Studies in Later Medieval Intellectual History in Honor of William J. Courtenay, ed. William O. DUBA, Russell L. FRIEDMAN, and Chris SCHABEL, Louvain, 2017 (Recherches de Théologie et Philosophie médiévales - Bibliotheca, 14), 
until recently was in the notebook of the Augustinian Pastor of Reggio Emilia from the 1310s, Vat. lat. 1086, which contains very brief summaries of disputational material by Master Gérard as well as a short question by Master Jean de Saint-Victor ${ }^{8}$.

Courtenay's new discovery of over 100 folios of the writings of the Victorine Pierre Leduc from the 1380s thus increases by several fold the total amount of works in academic theology known to survive from the Collège de Saint-Victor at the University of Paris ${ }^{9}$. Together with the biblical material that Gilbert Ouy attributed to Henri le Boulangier from the early fifteenth century ${ }^{10}$, as well as an incomplete set of questions on book I of the Sentences from around the same time that could be Victorine ${ }^{11}$, the biblical and sentential writings from Pierre Leduc suddenly present us with a wide window into Victorine theology and pride at Paris during the Great Schism. After presenting their scholastic works, this paper examines the two Victorines' attitude toward their Victorine heritage and endeavors to determine whether Victorine pride in the past was in any way an obstacle to independent thought for later members of the abbey, as one could argue was the case for many late-medieval Dominicans following Thomas Aquinas. Editions of the biblical principia or sermons of the two authors are offered in appendices.

\section{The Academic Works of Pierre Leduc and Henri le Boulangier}

p. 89-111, at p. 90, clarified its nature. The question, «Utrum theologia sit practica, speculativa, aut affectiva », is on part B, ff. 40ra-48vb (= ff. 282ra-291vb), the principium on ff. 37ra-39vb (= ff. 280ra$282 \mathrm{vb})$. Although the principium is anonymous, it is in the same hand as the question and together they occupy a quire. I will give further evidence in favor of this identification at the conclusion of this paper.

${ }^{8}$ On Gérard de Saint-Victor and his thought, see COURTENAY, Gerard of St. Victor and Amiens 234, and CROSSNOE, «The Philosophical Questions of Gerard of Saint-Victor ». The Jean de Saint-Victor in Vat. lat. 1086 may not be identical with the author of the same name who penned the Memoriale Historiarum: see PoIREL, L'école de Saint-Victor au Moyen Âge, p. 206, CROSSNOE, «The Philosophical Questions of Gerard of Saint-Victor», p. 89 n. 2, and the recent re-examination of the manuscript by William J. COURTENAY, « Reflections on Vat. lat. 1086 and Prosper of Reggio Emilia, O.E.S.A. », in Theological Quodlibeta in the Middle Ages. The Fourteenth Century, ed. SCHABEL, p. 345-375.

${ }^{9}$ William J. CourtenAY, Pierre Leduc, Victorine Master of Theology, and the Parisian Sententiarii in 1382, in Archives d'Histoire Doctrinale et Littéraire du Moyen Age, t. 87, 2020, p. 87-113. Some of the texts are edited in the same volume by SCHABEL, The Victorine Pierre Leduc's Collationes, Sermo finalis, and Principia on the Sentences.

${ }^{10}$ Gilbert OUY, Les manuscrits de l'Abbey de Saint-Victor. Catalogue établi sur la base du répertoire de Claude de Grandrue (1514), 2 vols., Turnhout, 1999 (Bibliotheca Victorina, 10), t. 1, p. 288, and t. 2, p. 514-517.

${ }^{11}$ In Paris, Bibliothèque nationale de France, lat. 14911, ff. 1r-107v. See below for details. 
Pierre Leduc (Petrus Ducis) was born around 1353 in Roissy, the location of Charles de Gaulle Airport. Pierre lectured on the Sentences at the Victorines in 1382-1383, just before his election as abbot of Saint-Victor in the late summer of 1383 . He was licensed in 1386 and called magister in theologia actu regens in late July 1387, so his first year as regent master at the Victorines was likely 1386-1387. He remained active as regent master and abbot until his death in June $1400^{12}$.

The library of Saint-Victor once held a volume of 129 folios containing « Sermones fratris Petri Ducis, quondam abbatis Sancti Victoris, tam de tempore quam de sanctis $»^{13}$, and another of 138 folios that an old catalogue labelled «Questiones lecture abbatis Petri Ducis super primum et secundum Sententiarum », but which the remainder of the entry suggests had a full set of questions on book I and an incomplete set on book IV:

in cuius libri foliis sequentibus hec habentur: utrum ab anima creata possit evidenter cognosci aliqua veritas (3); an essentia generet vel generetur (47). Tabula questionum et conclusionum in hoc primo libro contentarum (96). 99: Questiones super quartum: utrum curati vel priores parrochiales possint excommunicare suos parrochianos (132) ${ }^{14}$.

If they survive, these two manuscripts have not been identified, for although the manuscript that Courtenay identified contains sermons and materials linked to Pierre's Sentences lectures, Paris, Bibliothèque nationale de France, lat. $14800 \quad(=P)$ corresponds to neither of the lost manuscripts ${ }^{15}$. Its contents are rather as follows ${ }^{16}$ :

\footnotetext{
${ }^{12}$ For his life, see CROSSNOE, Victorine Education, p. 172-173; Sullivan, Parisian Licentiates, t. 1, p. 158-159; Courtenay, Pierre Leduc, p. 88-89 and 95-96; Rotuli Parisienses. Supplications to the Pope from the University of Paris. Volume III: 1378-1394. Part Two, ed. William J. COURTENAY and Eric D. GODDARD, Leyde, 2013 (Education and Society in the Middle Ages and Renaissance, 44), p. 578 (1387); letter of Pope Clement VII dated 4 November 1383, AAV, Reg. Aven. 237, ff. 387v-388v, water damaged: «(Dilecto filio) Petro Ducis, abbati monasterii Sancti Victoris extra muros Parisienses, (Ordinis) Sancti Augustini, salutem etc. Apostolice solicitudinis studium... [388r]... Dudum siquidem quondam (Petro [IV] abbate) monasterii Sancti Victoris extra muros Parisienses, Ordinis Sancti (Augustini), dicti monasterii presidente, nos, cupientes eidem monasterio... Postmodum vero, prefato monasterio per obitum ipsius Petri abbatis, (qui extra) Romanam curiam diem clausit extremum, abbatis regimine destituto, (dilecti filii) conventus dicti monasterii, reservationis et decreti predictorum forsan ignari, (te, canonicum?) dicti monasterii, bacallarium in theologia, ordinem ipsum expresse pro(fessum) et in sacerdotio constitutum, in eorum et dicti monasterii abbatem, lic(et de facto), per viam compromissi, concorditer elegerunt, tuque... consentisti. Et deinde, reservatione et decreto predictis ad tu(am deductis) notitiam, electionis huiusmodi negotium proponi fecisti in consis(torio coram) nobis. Nos igitur... ».

${ }^{13}$ OuY, Les manuscrits de l'Abbey de Saint-Victor, t. 2, p. 617, entry OOO 9.

${ }^{14}$ OuY, Les manuscrits de l'Abbey de Saint-Victor, t. 2, p. 95, entry L 22.

${ }^{15}$ See also COURTENAY, Pierre Leduc, p. 89.
} 
ff. $2 \mathrm{r}-7 \mathrm{v}$ (lost): first principium on Bible

ff. 8r-22v: an expositio on Ecclesiastes (23r-v: blank)

ff, 24r-28v: questions and dubia on Ecclesiastes (listed in Courtenay) (29r-v: blank)

f. 30r: fragment of second member of principium on Bible (30v: blank)

ff. 31r-32v: first member and start of second member of principium on Bible

ff. 33r-36r: second member of principium on Bible (incomplete)

f. 36v: new version of end of f. 36r and brief continuation of principium on Bible

f. 37r: end of the third principial sermon on the Sentences (37v: blank)

ff. 38r-40r: notes and dubia on book I of the Sentences (40v: blank)

ff. $41 \mathrm{r}-53 \mathrm{v}$ : questions and dubia on Matthew or Mark (54r-55v: blank)

ff. 56r-60v: principial sermons on the Sentences (ed. Schabel)

f. 60v: Sermo finalis on the Sentences (ed. Schabel) (61r: blank)

f. 61v: titles of principial questions on the Sentences

ff. 62r-79r (64bis, 78bis): principial questions on the Sentences (ed. Schabel) (73r-v, 79v: blank)

ff. 80r-88v: conclusions on book I of the Sentences

ff. 89r-102r: conclusions on book IV of the Sentences

ff. 102v-113r: conclusions on book II of the Sentences

ff. 113r-121r: conclusions on book III of the Sentences (121v-122v: blank)

The brief conclusions on the Sentences in Paris 14800 appear to be derived from Peter Lombard's textbook and are of no great interest. It is possible that they correspond to the conclusions mentioned in the table of contents of the lost manuscript formerly in the abbey library, but that manuscript also contained questions and was much longer, with nearly 100 folios for book I as opposed to a mere nine in Paris 14800.

All the texts relating to the Sentences, both lost and found, stem from Pierre Leduc's year as bachelor of the Sentences, 1382-1383. Courtenay rightly surmises that the biblical material is from Pierre's bachelor period as well, when it was customary to read a book of each testament, in this case in lectures probably given in 1379-1380 or 13801381, just after the outbreak of the Schism.

Courtenay was able to assign the above to Pierre Leduc with certainty via the socii whom Pierre cites and his self-identification as a Victorine named $d u x$. Likewise, I will argue on the basis of self-identification that there is no doubt that some of the material that Ouy attributed to Henri le Boulangier (Henricus Pistoris), apparently because of the handwriting alone, is by the Victorine. Despite claims that Henri was born about 1350

${ }^{16}$ This tabula tweaks the description in COURTENAY, Pierre Leduc, p. 89-90, 96, and 101-106. 
in an unknown place and entered the abbey of Saint-Victor around $1390^{17}$, only the latter piece of information is present in the short biography by the seventeenth-century Victorine historian Jean de Thoulouze. Yet if we are to trust Thoulouze for the date of Henri's entry into the order, then we should also consider his assertion that Henri was a Parisian: «Henricus Pistoris Gallice 'Boulenger' Parisinus circa annum 1390 sub abbate Petro Ducis canonicam vitam apud nos est professus $»^{18}$. The estimated date of birth of around 1350 may stem from the proposed dating of a Victorine sermon for Easter in French, attributed to Henri on the basis of the handwriting and dated ca. 1390 because of the watermarks ${ }^{19}$. Accepting the identification of the scribe, the attribution of authorship, and the date of the paper, we should still point out that 1390 is a terminus post quem, especially since the sermon is on a separate quire that could have stayed unused for a time. Based on his academic career, we would expect a birthdate of around 1370 instead.

Henri le Boulangier was licensed in theology in March 1409 and a note of sale in Paris, Bibliothèque nationale de France, lat. 14564, f. 333rb infra, records him as bachelor formatus in theology on 22 October $1405^{20}$. The two dates taken together make it likely that he read the Sentences in 1404-1405. Remarks in the biblical principium make it clear that this text is from bachelor lectures on the Bible, in which case they likely date to $1401-1402$ or 1402-1403, when he is first recorded as praebendarius ${ }^{21}$. It is thus probable that Henri did not even begin his theological studies until the mid1390s, and that in ca. 1390 he was a bachelor or new master of arts, a good time for a young Parisian scholar to join the Victorines, as Thoulouze claimed. Had he been born ca. 1350, in 1390 he would have been a forty-year-old arts master, not yet a theological student, joining the Victorines and giving a Victorine-inspired sermon, which is possible, but not likely. In any case, after his theological studies Henri remained active

\footnotetext{
${ }^{17}$ E.g., Olivier DELSAUX, Un prédicateur au travail. Édition du brouillon autographe D'un sermon inédit du victorin Henri Le Boulangier (ms. Paris, BnF, lat. 14921, fol. 100r-103v), in Neuphilologische Mitteilungen, t. 113, 2012, p. 219-239, at p. 219.

${ }^{18}$ JEAN DE ThOULOUZE, Antiquitatum regalis abbatiae Sancti Victoris libri duodecim, Paris, Bibliothèque nationale de France, lat. 14375, p. 316.

${ }^{19}$ DeLSAUX, Un prédicateur au travail, p. 220. Delsaux analyzes then prints the sermon on p. 227-236.

${ }^{20}$ Sullivan, Parisian Licentiates, t. 1, p. 289 (although the reference to Henri as bachelor of theology in January 1405 is 1406 new style); OuY, Les manuscrits de l'Abbey de Saint-Victor, t. 1, p. 14, and t. 2, p. 74.

${ }^{21}$ JeAn De Thoulouze, Annales abbatialis ecclesiae Sancti Victoris Parisiensis, Paris, Bibliothèque nationale de France, lat. 14372, ff. 363v, 366r, and 366v for « Henricus Pistoris praebendarius » on 20 October and 22 November 1402.
} 
in the abbey and at the university as prior and master respectively, for example representing the university as master and prior of Saint-Victor at the Council of Constance in 1415, and he probably remained in the same capacities until his death on 27 September $1419^{22}$.

According to Ouy, Paris, Bibliothèque nationale de France, lat. $7371(=H)$, contains the following texts, which he labelled in note 2 as «Euvre d'Henri Le Boulangier (Henricus Pistoris) $)^{23} »$ :

II 12.

125. Pars principii cuiusdam ${ }^{2}$ in theologia.

131. Pars expositionis cuiusdam ${ }^{2}$ super Ecclesiasten.

154. Pars principiorum cuiusdam ${ }^{2}$ in theologia.

II 20.

305. Glose super Cantica Canticorum. ${ }^{2}$

Even if we accept Ouy's identification of the handwriting as Henri's, this does not necessarily mean that the texts are by Henri, and a closer look appears to undermine his theory. Here is what I see in these sections of the manuscript:

ff. 125r-129v: a Victorine principium on Ecclesiastes (missing the start)

ff. $129 \mathrm{v}-130 \mathrm{v}$ : part of a Victorine commentary on Ecclesiastes, missing the start and ending abruptly in the prologue; folios with text have been cut out before and after $\mathrm{f}$. 130

ff. 131r-143v: Nicholas of Lyra's commentary on Ecclesiastes, ending abruptly at 7:30: «...per quam nulla rebellio esset in viribus sensitivis »

ff. 144r-153v: part of a Victorine commentary on Ecclesiastes, beginning at 1:8 and ending abruptly at $3: 14$

ff. 154r-160v: a Victorine principium on Ecclesiastes

ff. 160v-165v: a Victorine commentary on Ecclesiastes, ending abruptly at 1:7

ff. 305r-319r: Nicholas of Lyra's commentary on the Song of Songs

Of the 55 folios that Ouy assigned to Henri, almost half belong to Nicholas of Lyra. Since it would be odd for a bachelor to lecture on two books of the Old Testament, it makes sense that there is no Victorine commentary on both Ecclesiastes and the Song of Songs here, and indeed the incipit and explicit of the latter match those of Nicholas Lyra.

\footnotetext{
${ }^{22}$ For Henri's life, see OuY, Les manuscrits de l'Abbey de Saint-Victor, t. 1, p. 13-14, and t. 2, p. 195; CRossnoe, Victorine Education, p. 171-172; Sullivan, Parisian Licentiates, t. 1, p. 289-291.

${ }^{23}$ Ouy, Les manuscrits de l'Abbey de Saint-Victor, t. 2, p. 515-517.
} 
Regarding the material on Ecclesiastes, besides the section by Nicholas of Lyra (albeit with a lot of marginalia), there seem to be two principia and three fragments of commentary. The two principia on Ecclesiastes actually constitute different redactions of the same sermon. This is not rare in this period: the other principia from after 1380 that I have edited also exhibit this phenomenon, since there are a few overlapping fragments of different versions of Pierre Leduc's own principia on the Bible and on the Sentences, including one that I overlooked in my edition of his principia on the Sentences $^{24}$, and this phenomenon appears in the principia on the Sentences by Thomas Wölfel von Wuldersdorf from Vienna in 1433-1435. It is either by coincidence or by tradition that both Pierre and the author responsible for the Victorine biblical commentaries in Paris 7371 chose to lecture on Ecclesiastes, because Pierre's commentary does not match what we find in Paris 7371.

The three fragments on Ecclesiastes in Paris 7371 are not part of a single commentary. The segments on $H 129 \mathrm{v}-130 \mathrm{v}$ and on $H 160 \mathrm{v}-165 \mathrm{v}$ overlap in coverage and are not identical. Prima facie, the sections on $H 160 \mathrm{v}-165 \mathrm{v}$ and then $H 144 \mathrm{r}-153 \mathrm{v}$ seem to constitute one incomplete commentary going up to Ecclesiastes 3:14, but this is surely not the case. The text ending at the bottom of $H 165 \mathrm{v}$ does concern 1:7 and the text starting at the top of $H 144 \mathrm{r}$ does treat 1:8, but there are two problems. First, $H$ $165 \mathrm{v}$ has the catch-word eundo, since the text breaks off in the middle of a long quotation from Nicholas of Lyra that continues «Eundo propter hoc ripas suas... », but on the top of $H 144 \mathrm{r}$ Nicholas is no longer being quoted. Second, even ignoring the eundo, the transition does not work:

Consequenter ipse Salomon ostendit mutabilitatem circa elementum aque, dicens: omnia flumina intrant in mare, «quia etsi aliqua flumina aliquando absorbentur a

\footnotetext{
${ }^{24}$ A version of the end of Pierre's principium for book III of the Sentences is on $P 37 \mathrm{r}$, corresponding to p. 256.10-257.2 of the edition. These are the variants in that fragment $(=F)$ : p. 256.10-11: ista divisione] om. $F \| 14$ : Levi - fuit] Christus ut Levi non sit $F \|$ 17: natura] sit add. s.l. $F \|$ 18: ut creatura] talis natura assumpta $F$ (assumpta s.l.) $\| 20$ : sibi sit] $t$ r. $F \| 21$ : distinctione] om. $F \|$ 25: sive] vel a.c. s.l. $F \|$ 26: consequenter] om. $F \|$ p. 257.1: faciat] efficiat $F$; qui sine fine vivit et regnat] Dei Filius amen $F$. The fragment also contains the following alternative lines parallel to those in the edition: p. 256, 1. 13: Pater vel Spiritus si sit operatus || 14: Cur sicut alius (s.l.) non sit decimatus || 15: Ex quo sensu Christus sit praedestinatus. Other than that, $P 37 \mathrm{r}$ also has what appears to be an extra argument against Pierre's Dominican socius Jean le Gay on the relative superiority of the pope and the Virgin Mary: «Supplico quis status esset eligibilior, aut vivere cum peccato mortali <et> vivere in praelatione, aut vivere in gradu inferiori cum caritatis ardore? » For other fragments, see $P 61 \mathrm{v}$ (p. 240-241), $P 68 \mathrm{v}$ (p. 249 and 253), and $P 78 \mathrm{v}$ (p. 327).
} 
terra, alibi tamen exeunt et usque ad mare currunt. Et mare non redundat [1:7] [end 165v; start 144r] plus laboraverit [8:17]. Sequitur difficultas ad interpretandum vel docendum, cum dicitur non potest homo eas explicare sermone [1:8], aliis scilicet, et hoc plene et perfecte, quia etiam si Inon/ singula...

In the Vulgate, verse 1:7 continues with ad locum unde exeunt flumina revertuntur ut iterum fluant, and verse 1:8 begins with Cunctae res difficiles. As it stands, these phrases are ignored, which is not the practice elsewhere in these fragments.

Nor can one hypothesize that a folio or more is missing. When folio $H 165 \mathrm{r}$ begins, the Victorine is discussing the end of verse 1:3, so folio $H 165 \mathrm{r}-\mathrm{v}$ covers roughly four verses, i.e., all of verses 1:4, 1:5, and 1:6, plus parts of verses 1:3 and 1:7. Likewise, folio $H 144 \mathrm{v}$ concludes with the end of verse 1:11, sed nec eorum quidem quae postea futura sunt erit recordatio apud eos qui futuri sunt in novissimo, so folio $H$ 144r-v covers more than three complete verses, including 1:9 and 1:10. It is thus highly unlikely that the author's treatment of the end of verse 1:7 and the start of verse 1:8, less than one complete verse, would have taken up an entire folio. Therefore, it does not appear that these two fragments belong together. If not, then we cannot tell whether the fragment on $H 129 \mathrm{v}-130 \mathrm{v}$ or the fragment on $H 160 \mathrm{v}-165 \mathrm{v}$ goes with the fragment on $H$ $144 \mathrm{r}-153 \mathrm{v}$, and it is even possible that these three fragments are from three different texts.

A possible explanation suggests itself when one looks at common phrases in the overlapping sections of the two commentaries in the Prologue:

[129v] Verba Ecclesiastes filii David regis Ierusalem. Iste est secundus liber sapientialis ipsius sapientissimi Salomonis, cuius tempore, qui studium solempne vigebat in Ierusalem, cum circa varietatem et numerum capitum sentencia de felicitate hominis multiplicaretur, quam quidam in diviciis, alii in deliciis, et alii in honoribus mundanis ponebant et aliis multis per laborem humanum acquirendis in vita presenti.

[129v] Ipse Salomon, cum esset sapientissimus, ipsos reges et potentes desiderantes audire sapientiam eius, $3^{\text {ii }}$ Regum $4^{\circ}$, insuper et prophetum, de asipiscenda vera felicitate docui. [161v] ... sicut multi antiqui philosophorum, quorum quidam ponebant felicitatem hominis in deliciis, alii in divitiis, et alii in honoribus. Item, alii in aliis diversis bonis, que bona per humanum laborem acquiri possunt in presenti vita... 


\begin{tabular}{|c|c|}
\hline $\begin{array}{l}{[129 \mathrm{v}] \ldots \text { turbe sedicio comprimatur, per }} \\
\text { concionantis rationem ad unam scientiam } \\
\text { perductus, ut dicit Gregorius in Moralibus... }\end{array}$ & $\begin{array}{l}{[161 \mathrm{v}] \ldots \text { turbe sedicio comprimatur et tamen }} \\
\text { multi diversa senciunt, per concionantis } \\
\text { rationem ad unam sentenciam perducuntur, } \\
\text { ut dicit Gregorius in Dialogo... }\end{array}$ \\
\hline $\begin{array}{l}{[129 v] \text { Ubi notandum secundum venerabilem }} \\
\text { Hugonem nostrum ipsum Salomonem iuxta } \\
\text { tria eius nomina tres libros edidisse... }\end{array}$ & $\begin{array}{l}{[161 v] \ldots \text { et etiam venerabilis Hugo noster, }} \\
\text { qui et ab eodem accepit, quod ipse Salomon } \\
\text { iuxta tria nomina quibus nominatus est tres } \\
\text { libros sapientiales scripsit... }\end{array}$ \\
\hline $\begin{array}{l}\text { [start 130r] «in Bethleem positus ». Hec est } \\
\text { tertia pars Prologi, ubi insinuat ob cuius } \\
\text { favorem opus pretermissum consummavit, } \\
\text { dicens «et nunc in Bethleem positus, } \\
\text { augustiore videlicet civitate } \text { - quam Roma, } \\
\text { supple - «et illius », scilicet Blesille, } \\
\text { «memorie et vobis», O Paula et } \\
\text { Eustochium, «reddo quod debeo », id est, } \\
\text { quod ad petitionem illius inceperam ad } \\
\text { <instantiam> vestram perficio... }\end{array}$ & $\begin{array}{l}{[161 \mathrm{r}] \text { «... in Bethleem positus ». Hec est }} \\
\text { tertia pars Prologi, in qua beatus Ieronimus } \\
\text { insinuat ob cuius favorem opus pretermissum } \\
\text { consummavit, dicens «et nunc in Bethleem } \\
\text { positus, augustiore videlicet civitate } » \\
\text { quam sit Roma, supple - "reddo quod } \\
\text { debeo », id est, opus quod ad petitionem } \\
\text { sancte Blesille inceperam ad instantiam } \\
\text { vestram perficio... }\end{array}$ \\
\hline $\begin{array}{l}{[130 \mathrm{v}] \text {...ut dicit venerabilis Hugo noster. }} \\
\text { Prima est naturalis let apta/, secunda } \\
\text { culpabilis let perversa/, et tertia penalis et } \\
\text { misera. Describitur autem causa efficiens } \\
\text { huius libri, videlicet ipse Salomon, a tribus, } \\
\text { primo a sapientie profunditate [end } 130 \mathrm{v}]\end{array}$ & $\begin{array}{l}{[161 v] \ldots \text { In Proemio describitur causa }} \\
\text { efficiens, scilicet ipse Salomon, a tribus, } \\
\text { primo a sapientie profunditate... }\end{array}$ \\
\hline
\end{tabular}

There is much rearranging, but the two commentaries appear to be different redactions by the same author. Whoever compiled the manuscript may have had different quires in Henri's hand containing various drafts of Henri's sermons and commentary on Ecclesiastes, together with material by Nicholas of Lyra, and this compiler put them together as best he could. It is even possible that, before this, Henri himself collected what he considered the most useful parts of commentary on Ecclesiastes, some by himself, some by Nicholas.

As we will see below, in addition to following similar principia and being written by the same hand, what these two commentaries have in common is that they are both Victorine and both from the fourteenth or early fifteenth century, and yet both differ in style, content, and Victorine approach from Pierre's commentary. We can thus assume that the accompanying principium in two versions is not Pierre's missing sermon on Ecclesiastes. Given Ouy's opinion about the handwriting, and the paucity of other known Victorine bachelors of theology from these decades, his attribution to Henri is already likely. For the same reasons, Ouy's de facto opinion that the three Victorine fragments of commentary on Ecclesiastes were authored by Henri is also probable. In 
fact, I will argue on the basis of the thema of the principium on Ecclesiastes that Henri is definitely the author.

It remains to consider the incomplete set of questions on I Sentences mentioned above, on folios 1r-107v of Paris, Bibliothèque nationale de France, lat. 14911, formerly in the library of the Victorines. Gilbert Ouy determined that the first 9.5 folios of this work are in the hand of Henri le Boulangier, which, as Marshall Crossnoe remarked, « offers the possibility that the commentary is his $»^{25}$. The fact that the argument «In oppositum » for the very first question is a detailed citation and quotation from Hugh of Saint-Victor's De sacramentis (f. 1v) further strengthens the work's Victorine character, and citations of Gregory of Rimini, John of Mirecourt, Hugolino of Orvieto, and John of Ripa firmly establish the questions as originating from Paris after the 1350s. The text breaks off abruptly toward the end of distinction 4 at the end of a quire, but the bachelor had already reached his 41 st lecture of the academic year, since the lectiones are clearly marked in the style of the late fourteenth century, as in the case of Peter Plaoul in 1392$1393^{26}$. Pierre Leduc, for example, delivered 122 lectures in the 1382-1383 academic

\footnotetext{
${ }^{25}$ OuY, Les manuscrits de l'Abbey de Saint-Victor, t. 2, p. 102; CROSSNOE, Victorine Education, p. 171172; listed in STEGMÜLLER, Repertorium commentariorum in Sententias Petri Lombardi, t. 1, p. 491, no. 1250. The guards are made of three of four pieces of a Victorine charter that seems to date from 29 June 1353. After the Sentences questions, a separate codicological unit in various hands follows on ff. 108r$164 \mathrm{r}(164 \mathrm{v}-165 \mathrm{v}$ blank), dated the last quarter of fourteenth century and hence before Henri's lectures, containing «Conclusiones elicite ex secundo Sententiarum » on ff. 108r-123v, «ex tertio » on ff. 124r$137 \mathrm{v}$, and «ex quarto » on ff. 138r-164r. These conclusiones do not correspond to those of Pierre Leduc in Paris 14800 and are of little interest, at least prima facie. A third codicological unit on ff. 166r-181v from around the same time supposedly contains in the hand of Simon de Plumetot «Conclusiones elicite ex primo Summe Guillermi Altissiodorensis». The only citation of the manuscript I have found is in Peter BILLER, The Measure of Multitude. Population in Medieval Thought, Oxford, 2000, p. 127 and n. 61, quoting from f. 100rb, which Biller claims is from book II, d. 20, in a «commentary by an early Cistercian master, possibly Guy de l'Aumône (probably mid-1260s) »; this is an error for Paris, BnF, lat. 3424 , where the quotation is found on f. 100rb, and the text is definitely by Guy, who lectured between 1245 and 1253, as a bachelor. Patrick Monjou has kindly informed me that Morton W. BLOOMFIELD, Bertrand-Georges GUYOT, Donald R. HOWARD et al., Incipits of Latin Works on the Virtues and Vices, 1100-1500 A.D. Including a Section of Incipits of Works on the Pater Noster, Cambridge, MA, 1979 (The Mediaeval Academy of America Publications, 88), p. 552, includes Paris, BnF, lat. 14911 as a witness of the Compendium theologicae veritatis of Hugo Ripelinus, but since Paris, BnF, lat. 14912, which does contain the latter work, is not listed, the 14911 claim seems to be a misreading of the successive entries in Delisle LÉOPOLD, Inventaire des manuscrits latins de Saint-Victor conservés à la Bibliothèque impériale sous les numéros 14232-15175, in Bibliothèque de l'École des Chartes, t. 30, 1869, p. 1-79, at p. 38.

${ }^{26}$ Palémon GLORIEUX, L'année universitaire 1392-1393 à la Sorbonne à travers les notes d'un étudiant, in Revue des sciences religieuses, t. 19 (1939), p. 429-482; Jeffery C. WITT, Peter Plaoul's Lecture Commentary on the Sentences: A Canonical Ordered List of Lectures, in Manuscripta, t. 58, 2014, p. 159-270.
} 
year $^{27}$, so the author of the questions in Paris 14911 was not leaving himself much time for the remaining 44 distinctions of book I and the other three books.

As we shall see, in his authentic writings Pierre Leduc singles out John Duns Scotus, AdamWodeham, Rimini, Orvieto, and probably Mirecourt for praise and cites William of Ockham and Ripa, so the fact that all of these fourteenth-century figures are also cited in the questions in Paris 14911 suggests that Pierre could be the author. Nevertheless, the contents of Paris 14911 do not correspond to the description of Pierre's questions on the Sentences in lost manuscript mentioned above, in which one of the early questions (on f. 3) was «Utrum ab anima creata possit evidenter cognosci aliqua veritas ». This question is not among the questions (or their various articles) in Paris 14911, which are as follows:

Q. 1 (Prologue): Utrum viator insistens scripturis pure philosophantium cum rationis naturalis recto dictamine ad theologicas veritates sine fide lumine valeat pertingere (ff. $1 \mathrm{r}-24 \mathrm{v})$

Q. 2 (d. 1, q. 1): Utrum solo immenso et incommutabili bono sit licite fruendum (ff. 24v49r)

Q. 3 (d. 1, q. 2): Utrum possibile sit creaturam rationalem intuitive videre divinam essentiam sine persona et unam personam sine alia (ff. 49r-66r)

Q. 4 (d. 2, q. 1): Utrum Deum esse sit per rationem naturalem evidenter deducibile seu demonstrabile (ff. 66r-82r)

Q. 5 (d. 2, q. 2): Utrum Deum esse unum in essentia et trinum in personis sit a catholicis concedendum (ff. $82 \mathrm{r}-86 \mathrm{r}$; most of $82 \mathrm{v}$ is blank, much of aa. 1-3 are omitted, 83 is skipped in the numbering, and the final a. 4 begins on the top of f. 84 r)

Q. 6 (d. 4): Utrum Deus genuerit Deum de sua substantia seu de sua natura (ff. 84r-107v, ending at the start of the final a.4)

It is possible that the description of the lost manuscript is in error in ascribing it to Pierre Leduc, but it is more likely that the questions in Paris 14911, if they are indeed Victorine, belong to another Victorine bachelor lecturing at Paris after 1360, perhaps Nicolas Soloe, Nicolas de Morencourt, or, indeed, Henri le Boulangier, who may have adopted Pierre's doctrinal tendencies. I will return to this text in a separate study.

\footnotetext{
27 SchaBel, The Victorine Pierre Leduc's Collationes, Sermo finalis, and Principia on the Sentences, p. 239 and 262.
} 


\section{The Biblical Principia of Pierre Leduc and Henri le Boulangier}

As in the other faculties, series of lectures in the Faculty of Theology opened with sermons fittingly called principia $^{28}$. At Paris, bachelor lectures on the Bible preceded Sentences lectures by a couple of years and constituted the first independent teaching in theology of the advanced students, although under supervision. It was common to take a book of the Old Testament followed by a book of the New Testament, delivering two corresponding principia. There were four principial sermons on the Sentences, one for each book, but here the term principia also applied to questions and debates among the bachelors of the Sentences immediately following their opening sermons.

For their year as biblicus, Pierre LeDuc and Henri le Boulangier both lectured on Ecclesiastes first, but the quire with Pierre's first Bible principium is now missing from the manuscript and we know nothing at all about Henri's lectures on the New Testament. Thus we can only compare Pierre's second Bible principium, preceding his lectures on Matthew or Mark (the evidence is ambiguous), and his later principial sermons on the Sentences with Henri's first Bible principium, preceding his lectures on Ecclesiastes. Nevertheless, biblical principia were often only loosely linked - if at all to the specific book of the Bible that was to be the subject of the lectures, and this is the case here. Moreover, as Courtenay remarked, it was common to repeat material in one's principia and there are several indications that Pierre's second Bible principium is a continuation and partial reiteration of his missing first principium ${ }^{29}$. For the same reason, Henri's surviving first principium was surely a prequel to his principium given before whatever book of the New Testament he chose to cover. Thus the two biblical principia of the two Victorines are good comparanda.

One of the common characteristics of principial sermons in theology in this period was that the choice of thema and other central elements involved obvious or opaque references to the speaker, for example his name in Latin or the vernacular, or his place

\footnotetext{
${ }^{28}$ On principia in theology, see now William O. DuBA, The Forge Of Doctrine. The Academic Year 1330-31 and the Rise of Scotism at the University of Paris, Turnhout, 2017 (Studia Sententiarum, 2), p. 50-117, 221-232 (with editions on p. 299-324 and 361-376); COURTENAY, Pierre Leduc; SCHABEL, The Victorine Pierre Leduc's Collationes, Sermo finalis, and Principia on the Sentences; and William O. DuBA and Chris SCHABEL, The Rise of a New Genre of Scholastic Disputation: Principia on the Sentences, 1315-1350, Turnhout, forthcoming (Studia Sententiarum).

${ }^{29}$ Courtenay, Pierre Leduc, p. 105-106.
} 
of origin. In the case of our Victorines, they opted to identify themselves via their affiliation. In his Biblical principium, Pierre Leduc chose as his thema a quotation from Habakkuk 3:19 that showcased both his name and his abbey: Super excelsa mea deducet me Victor, immediately adding « ut in primo principio sumebatur », indicating that he had chosen the same thema for his now lost sermon before his lectures on Ecclesiastes $^{30}$. One could go further: the word super beginning his thema could be an allusion to Matthew 16:18, super hanc petram, which Jesus addressed to and meant Petrus, while excelsa mea could have brought to mind Ecclesiam meam in the same verse in the Gospel. The entire six-word thema was a pun on «Petrus Ducis ».

Henri le Boulangier was less subtle. The beginning of what I take to be the first redaction of Henri's sermon on Ecclesiastes is missing, so we have neither the thema nor the early divisions according to the thema, nor even the first main division. On the bottom line of $H$ 128r, at the start of a division and indented, one does finds the same quotation as in Pierre, albeit modified, from Habakkuk 3:19: «Super excelsa enim et specula deduxit eam Victor, Abacuc $3^{\circ} »$, but here Henri was merely collecting quotations that included the word «victor » or « victoria », for example II Ezra 4: Super omnia vincit veritas. The second main division indicates that the second word of the thema was est: «Quod probat veritatis stabilitas a nullo temerata, quia est », while the third main division leaves no doubt: «Quod probat eius nobilitas populo devulgata, quia victoria, ut tandem pro ipsius veneranda memoria concludi liceat quod Hec est victoria ». Thus Henri's thema in the first version was the same as that for his second version, from I John 5:4: «Hec est victoria, primae Iohannis quinto capitulo ». It is probably no coincidence that Henri's thema playfully consists of the words immediately preceding those in the thema of all four of Pierre's earlier Sentences sermons, also I John 5:4: Vicit or Vincit mundum fides nostra. Pierre and Henri thus chose themata identifying them as Victorines, and just as Pierre managed to allude to his name explicitly noting elsewhere «ego nobilis quia dux »-Henri's shorter thema Hec est victoria began with the pronoun $\mathrm{Hec}$, recalling «Henricus». In case the audience missed it, Henri brought up the pronoun frequently in the course of his sermon.

Pierre's second and only surviving biblical principium consists of two members, the second of which is incomplete. The first member, contained on $P$ ff. $31 \mathrm{r}-32 \mathrm{v}$, continues

\footnotetext{
${ }^{30}$ COURTENAY, Pierre Leduc, p. 106.
} 
the topic of the lost first principium and focuses on the role of the University of Paris in the war against heresy. In the first principium, Pierre had discussed «three battles and victories of the holy doctors against heretics », and now, in the first part of the first member, Pierre moves on to the fourth victory, introduced by what he calls a «puerilis ymaginatio » comparing heresy to the Hydra, which when one head is severed grows others, although in fact Pierre takes the entire analogy tacitly but verbatim from John Cassian. The first three battles took place in Late Antiquity before Charlemagne's mythical establishment of the studium of Paris, whereas the fourth was fought in the twelfth century, the subject of the first part of the first member. The second part of the first member moves the scene to the present day, the «last victory of the holy doctors », won by the University of Paris ${ }^{31}$.

Pierre's second member, on theology, is both incomplete and unpolished. The threefold division of the second member relates that the divine science is exalted above the other sciences, is governed morally and rejects all vices, and is attacked but its adversaries are laid low by its strong defense. This three-fold division is then expressed again in two three-fold divisions of the thema, for super excelsa, for deducit, and for victor. Only the first of the three parts is accomplished, on theology's superiority over the other sciences, but it is still longer than the entire first member.

Interestingly, Pierre wrote at least two versions of this section. One version, probably the first, is represented by the end of $P 32 \mathrm{v}$ immediately following the first member and perhaps the fragment on $P 30 \mathrm{r}$, which continues the text at the end of $P 32 \mathrm{v}$. The other version, probably the second, begins the second member on $P 33 \mathrm{r}$ and continues until the bottom of $P$ 36r, which seemingly ends the first part of the second member: «Et hoc de primo, in quo dicitur super excelsa ». Yet on the verso of $P 36$ some of what is on the recto is repeated and improved, and the text continues with some confusing notes that may come from a version of the second part of the second member. Afterwards, two folios have been cut out, which perhaps contained an unsatisfactory version of the rest of the sermon, i.e., the last two parts of the second member.

Although Courtenay describes what I call the first part of the second member as being «devoted to praising the role of the liberal arts », in which Pierre «credits

\footnotetext{
${ }^{31}$ See also COURTENAY, Pierre Leduc, p. 104-105.
} 
masters in the faculty of arts of having a part to play in the battle against heresy ${ }^{32} »$, Pierre is not quite so positive. One of the main differences between the two versions is that, at the start of the second member, the fragments of what seems to be the first version portray the practitioners of other sciences in a negative light, as glorifying their subject unduly. In one fragment, a quotation from Hugh of Saint-Victor shows by analogy that, just as animals love their offspring no matter how deformed they are, so do these scholars admire their subjects. Another fragment agrees with the second version that every human science has something of the divine, but when the second version continues blandly that «the divine science transcends the other sciences, but so that we see this more clearly » he will present those sciences, the first version is rather harsh: when they hear such praises of divine science from someone,

the ears of many listeners perk up. And « hearing these things », they were twisted to and fro « in their hearts, and they gnashed their teeth at him » [Acts 7:54], and «crying out with a loud voice», they even «stopped their ears » [Acts 7:56] in «the likeness of a serpent» and «the deaf asp» [Psalm 57:5], indeed in the likeness of a monkey, preferring the offspring of their own science. Neither the derision of those present nor the aversion of the wise ones had been able to chasten them so that they did not subtly recommend their offspring, that is, their sciences.

This passage was removed in the second version, it appears, perhaps to avoid causing offense.

The remainder is intended to show both that the divine science is superior to all the others - which, we are told after the first descriptions, are «but shadows and shades» of theology that « do not deserve to be called anything but its ancillary footservants »and that it beats each of them at its own game, despite the excessive praise of the nondivine scientists. The second descriptions thus show that, for example, the Bible (or divine science) is a better teacher of grammar than the grammarians, and the logician is told that he will be silenced by the «mystery of the Trinity, the perplexity of future contingents, the insoluble prognostication of divine predestination, and also the

\footnotetext{
${ }^{32}$ See also COURTENAY, Pierre Leduc, p. 104-105.
} 
inconceivable inquiry of reprobation $»^{33}$. The sequence and names of these other sciences differ in the second member, an indication of Pierre's leaving his text unpolished:

\begin{tabular}{|l|l|l|l|l|}
\hline 1st description & $\begin{array}{l}\text { 2nd } \\
\text { description }\end{array}$ & leader list & $\begin{array}{l}\text { end list a.c. } \\
36 \mathrm{r}\end{array}$ & $\begin{array}{l}\text { end list p.c. } \\
36 \mathrm{v}\end{array}$ \\
\hline grammar & grammar & grammar & grammar & grammar \\
\hline logic & logic & logic & logic & logic \\
\hline rhetoric & rhetoric & rhetoric & geometry & rhetoric \\
\hline natural phil. & natural phil. & & rhetoric & \\
\hline moral phil. & moral phil. & arithmetic & arithmetic & arithmetic \\
\hline geometry & astronomy & music $(p . c)$. & & music \\
\hline astronomy & arith. + geom. & geometry $(p . c)$. & astrology & geometry \\
\hline music & music & astrology & music & astrology \\
\hline medicine & med. + surgery & medicine & medicine & medicine \\
\hline law & law & law & law & law \\
\hline
\end{tabular}

Thus both natural philosophy and moral philosophy drop out; arithmetic, which was combined with geometry at the second stage, gets its own spot in stage three; surgery makes a brief appearance; astronomy turns into astrology at stage three; and stage four confuses the order, only to be corrected at stage five.

Unlike Pierre Leduc's second and sole surviving biblical principium, Henri le Boulangier's first and only biblical principium comes down to us in complete form, although in two redactions. The first redaction in the manuscript, which also appears to be the first redaction chronologically, is incomplete, probably missing the first folio. The second redaction in the manuscript and seemingly in sequence also adds a section continuing the sermon before beginning the commentary on the book of Ecclesiastes. The first redaction contains frequent modifications in the form of long passages crossed out, interlinear corrections, and extensive marginal additions. Some of these changes

\footnotetext{
33 These topics present such conundrums that they appear even in Pierre's exegesis, for example on chapter 6 of Ecclesiastes, $P$ 15r: «... scilicet notitiam futurorum contingentium, que non decet te scire. Ideo subditur sed et hec vanitas est, id est, inutile et presumptio Spiritus Sancti velle scire futura. Qui futurus est: Hic consequenter probat propositum de notitia vana et supersticiosa, et inducet ad hoc 4 rationes. Prima est quia solius Dei est scire futura, Ysaie 41... ideo stultissimum velle talium habere certitudinem... ».
} 
affect the second redaction, which also rearranges, removes from, and adds to the first redaction.

While Pierre announced two main divisions, Henri divides his principium into three, one for each of the three words of his thema, hec est victoria. The topic is war against the enemies of Jerusalem or Israel, which stands for the faith: the Bible fearlessly goes to war, constantly advances in war, and happily departs from war in glory with victory, having seized the crown. In a possible nod to Pierre, Henri's second member includes a discussion of the ancillary sciences, after remarking that « the superior wisdom contains much more perfectly the truth of all the inferior sciences, as declares the dux belli of the canons regular Augustine », who is elsewhere called «our special shepherd». Henri employs the motif of the tribes of Israel, Judah, Zebulun, and Naphtali, in battle against their enemies, to illustrate how, with the aid of holy men, Scripture defeats falsity, superstitious pseudo-science, and vice. With faith in God, Judah adduced grammar, logic, and rhetoric to assist Scripture in their war; putting their hope in strength, Zebulun employed metaphysics, medicine, physics, arithmetic, geometry, perspectiva, and astronomy, in ways prescribed by Vegetius; with caritas, Naphtali looked to ethics, monastica, economics, politics, laws, and decreta, in accordance with the advice of Seneca.

Although it is not emphasized, Henri sees the whole sermon as a giant consequence or syllogism in which the consequent or conclusion is the thema itself, hec est victoria: «Et per consequens pro eiusdem Sacre Scripture veneranda memoria non immerito preassumpsi quod hec est victoria. Consequentiam relinquo notam ». The first member thus begins «Consequentia igitur sic relecta, dico primo in antecedente... », the second «Dixi secundo in antecedente... », and the third constitutes the conclusion: «... merito concluditur pro $3^{\circ} \ldots »$, although the entire conclusion is also the thema: «tandem concludi liceat quod hec est victoria ». After the third member, both redactions have a brief gratiarum actio thanking the audience, «because you have added glory to my humility » in the first redaction, but switching « humilitas » to «parvitas » in the second redaction. The added section in continues the consequence/syllogism motif: «Quod est victoria, dico concludendo », especially in the final words, which refer to the consequent, the major, and the conclusion: «Et per consequens, habita maioris precedentis sufficienti memoria, concludi potest quod hec est victoria ». 


\section{The Victorine Character of the Principia of Pierre Leduc and Henri le Boulangier}

The edition of Henri le Boulangier's principium printed below includes the continuation in the second redaction, which is actually the opening of the first lecture on Ecclesiastes. Principia often concluded with brief divisiones textus of the book on which the speaker would lecture that term, but neither Pierre Leduc nor Henri includes this in the sermon proper. In Henri's first redaction the text moves immediately to a discussion of Jerome's prologue on Ecclesiastes, but in the second redaction Henri begins with a divisio textus as if adding a second concluding section to his principium given «previously». The passage is worth quoting in full, because it provides a reference to the audience, the context of a bachelor giving his first theological lecture series, the connection between the Bible and the principium, the limited role of the specific book of the Bible in that principium, and the reason for the thema:

Reverend fathers, now that, with God's support, according to the explanations of the doctors, I am about to lecture on the second sapiential book of the wise Salomon, which is called Ecclesiastes - not presumptuously, because it is for the sake of a necessary act and directed at my own training - I take up again the thema chosen previously in memory of the name of our blessed patron Victor for the recommendation of the entirety of Holy Scripture, now especially for the noble part of that same Holy Scripture contained in said Ecclesiastes and for the honor and glory of that same patron of ours Victor, stating that « This is the victory ».

Pierre Leduc packs his Bible and Sentences sermons with references to Christ as «Victor», as the «invictissimus Victor», the «aethereus Victor», or the «Victor potentissimus », as Courtenay notes ${ }^{34}$. Peter Lombard is described as the «vir victoriosus » or «victoriosus Parisiensis episcopus ». The theologians who defend the faith are «invincibiles» or «invictissimi ». There are repeated references to « victoria », and many forms of the verb « vinco » are scattered throughout the sermons: « vincit », « vicit », « vincere », « vincitur », « vincens », « vicerunt ». Henri too has numerous references to «victoria» in his sermon on Ecclesiastes, the first version of

\footnotetext{
${ }^{34}$ COURTENAY, Pierre Leduc, p. 105-106.
} 
which ends with «Deo autem gratias qui dedit nobis victoriam per Ihesum Christum Dominum nostrum, amen » $(H 129 \mathrm{v})$, while the second repeats the thema: «Et per consequens, habita maioris precedentis sufficienti memoria, concludi potest quod $\mathrm{Hec}$ est victoria » (H 160v). Whereas Pierre focuses on Christ «Victor», however, Henri makes his sermons more of a recommendatio Sacrae Scripturae, as required, and refers frequently to the Bible as the «Victrix», with repeated uses of the phrases «ipsa invictissima victrix Sacra Scriptura » and calling the students of theology in his audience «huius Victricis studiosi auditores ». When Henri does speak of the «Victor », it is not Pierre's Christ «Victor », but « Sanctus Victor, patronus noster », or even «gloriosus patronus noster». Overall, there are over 150 instances of words including « vict » in the two versions of Henri's sermon, and over 50 occasions where Pierre employs such terms in his principia on the Sentences and over 30 more in just the first division of his principium on the Bible. Pierre and Henri made every effort to identify themselves and their sermons with the Victorines.

Their expression of their Victorine identity is not limited to rhetoric, however. What survives of Pierre's second biblical principium is divided into two topics, as we have seen, the first a history of the Christian battle against heresy culminating in the present University of Paris and the second a discussion of the sciences that are merely ancillary to theology. Aside from quoting from Hugh of Saint-Victor on occasion as a source for his history, Pierre lists two Victorines in his verse celebration of the great twelfthcentury theologians associated with France in one way or another:

Anselm of Canterbury most subtle in genius

Bernard of Clairvaux most devout in study

Lombard the Parisian most constant in the stadium

Our Hugh the Saxon most acute in scrutiny

Richard the Victorine most strong in this battle

If the reader will not take his word for it concerning the Victorines, then Pierre quotes Vincent of Beauvais' praise of Hugh and Richard: Hugh was a leader in the seven liberal arts and Richard's De Trinitate was the best work on the subject, strong enough words that one can understand Pierre's desire to hide behind Vincent. In other verses, 
paraphrased here, Pierre associates the five leaders with the errors they defeat in their writings:

Anselm, On the Procession of the Holy Spirit, overcomes the Greek

Bernard, with his letters, refutes Abelard

Lombard, with his Sentences, defeats the condemned Abbot Joachim

Hugh, On the sacraments, shatters various errors

Richard, On the Trinity, troubles the Porretan

Even after the great period of these «invincible doctors, even the Victorine doctors of this church [of Saint-Victor] », even now, in the late fourteenth century, Pierre begins his verse list of legions fighting against the Antichrist with his own kind: Canons Regular, Conventual Monks, Preachers, Friars Minor, Augustinians, Carmelites, Bernardists, and members of other Colleges.

Some of these elements reappear in Pierre Leduc's principial sermons on the Sentences, as Courtenay remarks, although the overall theme shifts slightly from heresy to battle, even if heresy remains prominent. In the sermon for the second book of the Sentences, Pierre repeats his verse concerning the five champions of the twelfth century, but not the verse about their vanquished opponents or the quotation from Vincent of Beauvais. In the speech for book III Pierre enlists only the first four in support of one of his favorite doctrines, the immaculate conception of the Virgin Mary. In verse Pierre emphasizes that Lombard of Paris attested to her maternity, Bernard of Clairvaux to her chastity, Anselm of Canterbury to the miracle of her holy conception, and « our Hugh the Saxon » to her being without macula, thus giving the Victorine pride of place. In the sermon on the fourth book Hugh is elevated still further, because the subject is the sacraments and the four leading authorities stretch back to antiquity: Ambrose, our Hugh, Peter Lombard, and Cantor, i.e., Petrus.

Henri le Boulangier's biblical principium focuses on the topic of battle and war, but without the stress on heresy, so perhaps Pierre's sermons on the Sentences were Henri's inspiration, or maybe Henri simply wanted to accommodate his thema of victoria. In addition to his references to the patron Saint Victor himself, Henri further emphasizes his Victorine heritage in personal ways. Henry addresses his audience with the normal « Reverendi patres ac domini » in three crucial places, but at the start he emphasizes his 
inadequacy before their seniority and elevated intellects, so he only proceeds because he is « compelled by reason of the present act », «complying with the orders of my lord abbot and all the other religious of this church », that is, the Church of Saint-Victor, the abbot being then Geoffroy Pellegay.

More frustratingly, not long afterwards Henri mentions what his own «master » dealt with in the past: « de quo pridem solempniter magister et dominus meus prior de Putheolis ». There is no doubt that this person was a Victorine, since the priory of Notre-Dame-de-Puiseaux, about $80 \mathrm{~km}$ south of Saint-Victor, was a Victorine foundation. None of the Victorine masters listed above fits this description, so either Henri is using the term «master » in the loose sense of «teacher » or perhaps a secular master joined the Victorine community at a later date and become prior of Notre-Damede-Puiseaux, but whether he taught or gave a sermon at Saint-Victor «pridem » is unclear.

In his sermon, Henri quotes no less than eight Victorines from the classic twelfthcentury school $^{35}$. Not surprisingly, Henri has more than a half-dozen references each to « venerabilis Hugo noster» and «venerabilis Richardus noster », citing various works. In addition, Henri cites twice each both «venerabilis Adam noster », « in prosa » and « in suo dyalogo», and «venerabilis quondam frater Gaufridus canonicus huius ecclesie », i.e., Godefroy de Saint-Victor, once «in sermone ». There are two citations of «Galterus quondam prior huius ecclesie », once « in sermone », Gauthier being prior from 1173 to his death around 1180. Henri refers once to « reverendus quondam in Christo pater magister Achardus canonicus huius ecclesie, post episcopus Abricensis, in sermone », perhaps forgetting that Achard served as abbot in 1155-1162 before becoming bishop of Avranches. In contrast, Henri's four mentions of Abbot Absalon, three times specifying a sermon (including « reverendus quondam pater meus Absalon abbas huius ecclesie in quodam sermone »), reveal that there was (understandable) confusion among the later Victorines between Abbot Absalon (1198-1203), from whose pen nothing has been identified, and the Victorine canon and master Absalon active before become abbot elsewhere by 1193, who authored numerous Sermones festivales. There is no such confusion in Henri's three citations of Abbot Guérin (1172-1193/95),

\footnotetext{
${ }^{35}$ For concise information on the Victorines whom Henri cites, see POIREL, L'école de Saint-Victor au Moyen Âge, p. 192-202.
} 
«abbas quondam noster venerabilis Garinus », once specifying «Guarinus quondam abbas huius ecclesie in quodam sermone ».

Finally, beyond these eight, there is one mention of what «expertus Johannes quondam abbas huius ecclesie » stated. By Henri's time there had been three Abbot Johns of Saint-Victor, in 1203-1229, 1311-1329, and 1349-1360, but none of them seems to fit. The context is not philosophical theology either, so we can exclude the texts by Jean de Saint-Victor in Vat. lat. 1086, and it does not appear to correspond to the Memoriale historiarum of Jean de Saint-Victor either, also from the first half of the fourteenth century. A more likely target is Jean d'Aulnay, canon of Saint-Victor, the author of a number of sermons in Paris, Bibliothèque nationale de France, lat. 14961, active in the third quarter of the thirteenth century ${ }^{36}$.

With his 30 or so citations of nine Victorine authors, his choice of thema, and his use of terminology, it would appear that Henri le Boulangier's primary concern was to emphasize his religious identity. As we have seen, at the end the added section of his speech, about to begin commenting on Ecclesiastes, Henri reminds his audience of the context and concludes that he spoke « for the honor and glory of that same Victor, our patron, saying that 'this is the victory' ».

\section{The Biblical Exegesis of Pierre Leduc and Henri le Boulangier}

To what extent did Victorine pride and loyalty in their principial sermons on the Bible extend to their exegesis? If Henri le Boulangier's lectures on a book of the New Testament survive in any form, they have not been identified. For Pierre Leduc, all we have are what are labeled in the colophon on P 41r as dubia on Matthew or Mark, but in the incipit of the text as dubia on Matthew, while the colophon for the earlier second biblical principium on $P 31 \mathrm{r}$ attaches that to Mark. Either way, these dubia, 221 in all according to Courtenay's count, are only occasionally linked to the synoptic Gospels, and all but the last two are limited to a paragraph ${ }^{37}$. There is little in the way of postpatristic citations, with a reference to Bernard, one each to two works of Anselm, a half dozen to Peter Lombard, and seven to the Victorines, six of which are to Hugh and one

\footnotetext{
${ }^{36}$ PoIrEL, L'école de Saint-Victor au Moyen Âge, p. 204-205.

${ }^{37}$ CourtenAY, Pierre Leduc, p. 106.
} 
to Richard, the sole remark establishing Pierre's identity ( $P$ 48r): «Unde sicut dicit Ricardus noster... ». Nevertheless, the very first and last citations of authorities in the dubia are to Hugh of Saint-Victor. Indeed, as if to finish on a personal note, Pierre concludes with a confirmation from Hugh (P 53v):

\begin{abstract}
Confirmatur per venerabilem Hugonem, De sacramentis, libro $2^{\circ}$, parte $14^{\mathrm{a}}$, capitulo $6^{\circ}$, ubi ad istud propositum ex intensione sic dicit: «Totum ergo meritum in voluntate est; quantum vis, tantum mereris ». Ergo similiter est de demerito. Et subdit Hugo: «In voluntate totum meritum est, nam opus sive sit sive non sit, nichil minus in voluntate est, nisi forte in hoc quia voluntas maior fieret si opus fieret ». Et subdit: « Si forte contingerit tantam esse voluntatem in eo qui non operature quanta est in illo qui opus exercet, ubi voluntas eadem est, meritum dissimile esse non potest ».
\end{abstract}

Pierre then adds, «Ergo tota conclusio vera », and ends the entire set of dubia four lines later.

The two colophons for the commentary on Ecclesiastes in the Pierre Leduc manuscript describe it as «secundum Nicolaum de Lyra », but Courtenay states that it actually follows Bonaventure's commentary, occasionally attributed to Nicholas of Lyra (ca. 1270-1349), even if Pierre's commentary is different ${ }^{38}$. In fact Pierre actually cites Bonaventure in the text in chapter 7 ( $P$ 16r), but perhaps Pierre was looking at another work of the Franciscan. Pierre also cites Nicholas of Lyra explicitly at least three times (chapter 5, $P$ 14r, twice; chapter 9, $P$ 19v), but the clearest indication of Pierre's relative independence is his reference to Pope Benedict XII's pronouncement on the Beatific Vision (i.e., Benedictus Deus, chapter 7, P 15v) from 1336, which postdates Nicholas' Postilla, written at Paris in the 1320s.

Pierre's reference to Benedict XII further suggests that he was interested in systematic theology as much as exegesis, and this is borne out by his reference to several works of Aristotle, along with the occasional mention of the likes of Boethius and Seneca, and the odd excursus into such philosophical topics as foreknowledge of future contingents (chapter 6, $P$ 15r). Pierre's Victorine identity is hardly evident at all, with just three citations of Adam of Saint-Victor in the Prologue ( $P$ 8r-v, once as

\footnotetext{
${ }^{38}$ COURTENAY, Pierre Leduc, p. 101-102.
} 
« magister Adam de Sancto Victore » and twice merely as Adam ») and three references to « Hugo » in chapter $1(P$ 9v-10r).

In contrast, Henri le Boulangier's commentary on Ecclesiastes is strikingly Victorine. Hugo of Saint-Victor is by far the most cited authority, receiving 41 references in all three fragments, one as «Hugo noster», sixteen as "venerabilis Hugo », and 24 as «venerabilis Hugo noster ». A number of these include direct quotations, sometimes quite long ones, indicated at the end by remarks of the «Hec ille » sort, presumably from Hugh's popular but incomplete nineteen Homilies on Ecclesiastes, going down to 4:8, a surviving copy of which is annotated by Henri himself ${ }^{39}$. Occasionally Hugh's authority is placed on the same level as that of Jerome himself, as on chapter 2: « ... prosequitur beatus Ieronimus et venerabilis Hugo noster valde pulchre » $(H 151 \mathrm{v})$. Hugh's treatment is described as «valde pulchra » on three other occasions, but more often Henri comments on how long winded his champion is, as in chapter 1: « ... et cetera valde pulchra, quamquam prolixa, venerabilis Hugo » $(H$ 165r); chapter 2: «Istum textus venerabilis Hugo noster prolixe prosequitur, quem causa brevitatis dimisi » (H 148r), «Et de hoc ponit venerabilis Hugo exemplum de Moyse et Rubo, quod pro nunc dimitto quia prolixum est» (H 150r), «prout per prolixum processum pulchre declarat venerabilis Hugo noster » ( $H$ 150v), and «Hanc brevem sententiam prolixe prosequitur Hugo noster, quam dimitto brevitatis causa » $(H$ 150v-151r); and the final chapter 3: «... multe notabiles et fructuose allegorie quas ponunt tam Ieronimus quam etiam venerabilis Hugo noster, quas hic dimitto. Siquis voluerit videre, ostendam ei » ( $H$ 153v). This last quotation again ties Hugh to Jerome, concluding in an interesting reflection of the oral nature of the text: «If anybody wants to see [these allegories], I'll show him ».

Aside from Hugh of Saint-Victor, Henri does refer once to «venerabilis Richardus noster » (chaper 1, H 147v), further establishing his Victorine identity. Henri also cites Nicholas of Lyra three times and makes the occasional reference to the works of Aristotle, which, in addition to a dubitatio here and there, is the limit of the philosophical nature of the commentary. Aside from the above and a couple of mentions of Bernard and one to Alcuin (Prologue, $H$ 161v), Henri takes his inspiration, and sometimes his very words, from « our venerable Hugh ».

\footnotetext{
${ }^{39}$ OuY, Les manuscrits de l'Abbey de Saint-Victor, t. 2, p. 262: Paris, BnF, lat. 14505.
} 


\section{Conclusion: Pride and Independence}

Victorine pride was a psychological boost for the later-medieval Victorines, not a doctrinal burden. Unlike the Dominicans' obligation to follow their canonized teaching doctor, the relatively recent Thomas Aquinas, the Victorines had not put their members in a would-be doctrinal straightjacket. Rather the three Victorines from whom we have unabbreviated writings in philosophical theology from the long fourteenth century reflect the evolution of the field in that same era.

This pride and flexibility is evident in the main early example of Victorine philosophical theology at the University of Paris, the principial sermon and question on the Prologue of the Sentences by Gérard de Saint-Victor from around 1300 and extant in Amiens 234. In his brief principium in praise of theology, the Bible, the Lombard, and his Sentences, Gérard makes a point of citing Hugh's Didascalicon and Richard's De Trinitate once each ${ }^{40}$. Yet even in a sermon in praise of theology and Scripture there are more frequent references to Aristotle, Avicenna, and Averroes. In Gérard's long question on the nature of theology that follows, the pagan and the two Muslims, along with Al-Ghazali, provide the main philosophical framework for the entire discussion, although Augustine also plays a role. The Christian opinions with which Gérard engages are those of recent or living theologians labelled in the margins: the Augustinian Giles of Rome, the Dominican John Quidort (whom Gérard «audivi »), the secular Henry of Ghent (twice), and two others who are harder to identify, «Bertaudus » and «Richardus », whom Courtenay suggested are the late-thirteenthcentury theologian Berthaud de Saint-Denis and Richard de Saint-Victor, but it seems more probable that the latter is the Franciscan Richard of Menneville (Mediavilla) ${ }^{41}$. The question continues with attacks and counter-attacks, with more appearances of Aristotle and the Muslims. It is only in the conclusion to the question, in a rhetorical

\footnotetext{
40 Amiens 234, f. 38ra: «... sicut dicit H., Didasc', libro <5> [8], ca. 6: 'Geminus', inquit, 'divine lectionis fructus...' », and f. 38rb: «... sicut expresse dicit Ri. libro $1^{\circ}$, ca. ${ }^{\circ} 3^{\circ}$ : 'Ad notitiam', inquit, 'eorum de quibus nobis recte dicitur...' ».

${ }^{41}$ CourtenAy, Gerard of St. Victor and Amiens 234, p. 60, notes that Gérard cites Henry, Giles, John, Berthaud, and Richard. In the manuscript the references are, in the secundum principale, Amiens 234, $\mathrm{f}$ 41rb: «1 opinio: Egidius »; f. 41va: « 2 opinio: Iohannes Par” »; f. 42ra: « 3 opinio: Hugo (!) de Gandavo » («Dicunt enim in Summa sua, q. LVIII, ar. VI... » « ut magis dicetur et patebit in prima questione sequentis articuli, scilicet LIX... »); in the tertium principale, f. 45vb: "opinio 1: Henrici » (“dicunt enim in Summa sua, ar. 8, 5, 7 »; f. 46va: « opinio 2: Bertaudus » and « Richardus ».
} 
summing up, that one finds Gérard's only nod to his Victorine identity ${ }^{42}$, another reference to Hugh's Didascalicon, as if to bookend the whole package after the initial reference to the same Victorine work in the principium $^{43}$.

At the University of Paris in 1300, a bachelor of theology lecturing on the Sentences with up to a dozen competing bachelors could not rely on twelfth-century ideas and methods to defeat his adversaries and convince his audience. The influx of translations of the rest of the Philosopher, of his main Commentator, and of Avicenna, and then their full absorption into the new university curriculum and environment, marginalized the twelfth-century Victorines and even Peter Lombard himself. Richard remained important in trinitarian questions, and outside the school Anselm rose to the level of a Church Father, but generally scholastics had to stay with the times. As Marshall Crossnoe has remarked in connection with what remains of Gérard de Saint-Victor's later quodlibetal questions, it is thus difficult to place Master Gérard in the Victorine tradition, because « Latin academic theology and philosophy in 1315 was very different from what it was in 1125 or $1215^{44} \gg$.

By the start of the Great Schism these tendencies toward novelty were if anything even more pronounced, as is evident in the trendy debates recorded in Pierre Leduc's principial questions. Thus when Pierre dealt with current issues in philosophical theology, as in his dubia on Ecclesiastes, he was free to quote the Dominican Thomas Aquinas six times (II Sentences and the II $^{\mathrm{a}}$ II $^{\mathrm{ae}}$ of the Summa theologiae), the Franciscan Bonaventure four times (although the Compendium, actually a work of Hugh Ripelin of Strasbourg), the secular Henry of Ghent four times (Quodlibeta), and the fourteenthcentury Carmelite John Baconthorpe three times (IV Sentences) ${ }^{45}$. In contrast, Pierre cited his Victorines only at the very beginning and end, mentioning Adam in chapter 1 ( $P$ 24r): «ad hoc dicit magister Adam in prologo super 3 libros Salamonis » and refering the reader to Richard in the last chapter $(P 27 \mathrm{v})$.

We have seen that Pierre quoted Hugh of Saint-Victor at the start and finish of his dubia on Mark or Mathew, but in addition to two mentions each of canon law and of

\footnotetext{
${ }^{42}$ Aside from what might be a Victorine-inspired comment in the margin on Amiens 234, f. 45va: «Non enim debet denominari aliquid a fine nisi et remoto, ut quamvis finis omnium bellantium sit victoria, quia tamen lest/ finis proprius ducis et communis omnium aliorum, solus dux belli dicitur victor et nullus aliorum... ».

${ }^{43}$ Amiens 234, f. 48rb: « sicut dicit H. secundo Didascalicon... ».

${ }^{44}$ CROSSNOE, «The Philosophical Questions of Gerard of Saint-Victor », p. 107-108.

${ }^{45}$ See for most of these references the summary and analysis of COURTENAY, Pierre Leduc, p. $102-104$.
} 
Aristotle, including one to De caelo $(P$ 41r), Pierre also cites some thirteenth-century university theologians: Alexander of Hales twice $(P 49 \mathrm{v}, 50 \mathrm{v})$ and both Godfrey of Fontaines $(P$ 50v) and Thomas Aquinas $(P$ 49r) once each. More importantly, Pierre does not hesitate to refer to more recent figures: the Carmelites Gerard of Bologna ( $P$ $44 \mathrm{v}, \dagger 1317)$ on prophecy and grace and Guy Terrena $(P 44 \mathrm{r})$ in the context of heresy (probably the Summa de haeresibus, ca. 1340), and two stars of the 1340s, Thomas Bradwardine ( $P$ 46v: «Doctor Ebroardim ») on perseverantia ${ }^{46}$ and the Augustinian Gregory of Rimini, who is cited along with Aquinas and «certain new doctors », who must have been active after 1350 ( $P$ 49r): «Oppositum tamen ponunt Doctor Sanctus, Magister Gregorius, et quidam novi doctores. Unde Gregorius contra Magistrum... ». Other vague mentions of «aliqui », «quidam doctores», and specifically «quidam doctor $\gg(P 43 \mathrm{v})$ may thus also refer to other late-medieval theologians.

In his principial sermon on the third book of the Sentences, Pierre repeated his list of modern battalions defending Christianity, ranking them again as follows: Canons Regular, Conventual Monks (Collèges de Cluny, de Marmoutiers, etc.), Preachers, Friars Minor, Augustinians, Carmelites, Bernardists, and members of other Colleges ${ }^{47}$. In the fourth sermon, however, after listing the four old authorities on the sacraments, Ambrose, our Hugh, Peter Lombard, and Peter the Chanter, Pierre now adds in verse the new doctors, the ones with whom a contemporary would be in dialogue: Thomas Aquinas OP, Alexander of Hales OFM, Gregory of Rimini and Hugolino of Orvieto OESA, John Duns Scotus and Adam Wodeham OFM, William of Auxerre, William of Auvergne, and the Cistercian Monk, most likely John of Mirecourt, a copy of whose questions on book I of the Sentences Pierre ordered to be copied in his student days ${ }^{48}$. In addition to these nine theologians of the university era, five of them active in the fourteenth century, Pierre concludes with a tenth, who «harmonizes the new [doctors] with the fathers, Brother Peter of Candia », the Greek Franciscan and future Pope Alexander V, who had only just completed his own lectures on the Sentences four years

\footnotetext{
${ }^{46}$ Paraphrasing from Thomas BradWARdinus, De causa Dei contra Pelagium et de virtute causarum II, c. 8, corollarium, ed. London, 1618, p. 497D-E, and c. 12, p. 508B.

47 See also COURTENAY, Pierre Leduc, p. 105.

${ }^{48}$ OuY, Les manuscrits de l'Abbey de Saint-Victor, t. 2, p. 99 (presently part of Paris, BnF, lat. 14570, ff. 77-149); COURTENAY, Pierre Leduc, p. 107.
} 
earlier, was licensed during the 1381-1382 academic year, and thus was serving as Minorite regent master in 1382-1383 while Pierre Leduc spoke these words ${ }^{49}$.

Probably these ten theologians inspired Pierre in his Sentences lectures, but in his principial questions his task was to debate his socii on the hottest issues of the day. Thus in 72 dense pages in the critical edition ${ }^{50}$, while Pierre employs a variant of the word «victor» on average almost once per page, specifically mentioning Christ «Victor» in every question title ${ }^{51}$, until the end he only cites his Victorine ancestors four times in passing, Hugh twice (I, p. 264.14; I, p. 275.11-12) and Richard (I, p. 269.11) and Adam (III, p. 305.12-13) once each. In contrast, Pierre ends his first principium by copying 100 lines from the fourteenth-century Oxford Franciscan William of Ockham's Ordinatio on book I of the Sentences (I, p. 280-282), and elsewhere he cites Ockham's Summa logicae (IV, p. 332.5), the Sentences questions of the Franciscans John Duns Scotus and Adam Wodeham (I, p. 266.15), alludes to Scotists (I, p. 278.32), and ranges Wodeham and Ockham against Scotus (II, p. 296.1821). Much of the discussion involves philosophical and theological problems that were not treated in the same way before the fourteenth century, for example because of the decree Benedictus Deus of 1336, Pope Benedict XII's definition of the Beatific Vision, cited in the second principium (II, p. 286.9). Some issues are even from after the Black Death and the activities of the Franciscan John of Ripa from the 1350s and 1360s, once when Pierre quotes «quidam doctor» (I, p. 265.36-266.7), perhaps a follower of Ripa, and once when Pierre cites «magister Iohannes de Rippa » explicitly (II, p. 288.2).

The only time Pierre Leduc reaches back into the thirteenth century it is to quote Aquinas' Summa theologiae II $^{\mathrm{a}}$ II $^{\mathrm{ae}}$ in the third principium (III, p. 300.30-301.6), not necessarily as an authority tout court, but in order to use the Dominican teaching doctor against his Dominican socius Jean le Gay, in order to argue against le Gay that it is better to be a simple person with grace, like the Virgin Mary, than a pope without. For

\footnotetext{
${ }^{49}$ Sullivan, Parisian Licentiates, t. 1, p. 117-118; COURTENAY, Pierre Leduc, p. 107-108, who suggests that Pierre risked «possibly offending other regent masters who were not similarly mentioned and thus honored (among them Pierre d'Ailly and Henry Totting of Oyta) ». Henry Totting of Oyta had already left Paris, however, and in his lifetime Candia was more prominent than d'Ailly: Sullivan, Parisian Licentiates, t. 2, p. 49-53, 525-528.

${ }^{50}$ SChabel, The Victorine Pierre Leduc's Collationes, Sermo finalis, and Principia on the Sentences, p. 263-334, cited below in parentheses in the text according to principium and page.

${ }^{51}$ COURTENAY, Pierre Leduc, p. 107.
} 
this position it was just as important that Pierre cited the recent chancellor of Paris (1370-1380) Master Jean de Chaleur as being in agreement (III, p. 306.36-38).

This was in the context of Pierre's acrimonious debate over Mary's immaculate conception, a doctrine that only became popular in the fourteenth century, except among the Dominicans, following Aquinas. Pierre's independence from Aquinas and only real nod to his Victorine doctrinal heritage comes at the conclusion of his fourth and final principium question, ending his exchange with le Gay on the immaculate conception (IV, p. 334.6-31):

It seems to me that he [Jean le Gay] rather clearly excites a dog that wants to sleep, namely reciting those opinions that we must never mention. So I was moved to express the more common opinion [in favor of the Immaculate Conception]... Although there are [different] opinions on her conception, nevertheless the one that I hold is most pious and grows stronger from day to day, such that against one disbeliever there are one hundred adhering to this truth... This was also the opinion of my venerable doctors and fathers, master Hugh, Richard, and Adam [de Saint-Victor], who were the roots and the shoots of the Faculty of Theology here at Paris, and they preached this opinion 140 years before Thomas [Aquinas]! So although our voice has resounded in some places louder than in others, it has not abandoned the struggle of our fathers.

In the principial debates of 1382-1383, one could not wage war without the weapons forged in the fourteenth century, although, as Courtenay remarks, with his citations it appears that Pierre « did not see a confrontational divide between a via antiqua and a via moderna $»^{52}$. The backlash came as the Schism wore on. When Henri le Boulangier represented the University of Paris at the Council of Constance in 1415, he accompanied Jean Gerson and Pierre d'Ailly, who were kindred spirits. Henri is associated as owner, scribe, or user of many books formerly in the library of SaintVictor, but the only works in philosophical theology from the university era were questions on the Sentences by Bonaventure, John Duns Scotus, and Durand de SaintPourçain $^{53}$, close to Gerson's famous recommendation to students of the Collège de Navarre, dated 1400, of Aquinas, Bonaventure, and Durand as the doctors who wrote

\footnotetext{
${ }^{52}$ CourtenAy, Pierre Leduc, p. 108, and p. 108-113 for a summary of the topics in the debates.

${ }^{53}$ OuY, Les manuscrits de l'Abbey de Saint-Victor, t. 2, p. 74 and 80.
} 
more purely and solidly ${ }^{54}$. Henri's very frequent citations of his twelfth-century Victorine forefathers would fit in very well with this conservative trend during the Schism to return to safer doctors.

Both Pierre and Henri emphasized the inferiority of the other sciences to theology, however, and what I deem their first versions or redactions both included passages that portrayed these sciences in a negative light. In Henri's third member there is a long section against silly arguments, curious comments, fantastic images, and fallacious sophistry. Via the traditional simile of shaving the captive women before marriage, Henri recognizes that these sciences are useful in theology, once shorn of what is dead, but they must be controlled. Henri removed this passage in the second redaction, but in the section added to the second redaction between the sermon and the commentary Henri attacks vana curiositas and falsa felicitas, continuing the theme into the expositio itself, although this is part of any approach to Ecclesiastes.

Even if Henri was part of a back-to-the-good-old-days movement, this does not mean that it was because of his Victorine identity. The philosophical attitudes of Gérard de Saint-Victor, Pierre Leduc, and Henri le Boulangier were typical of their different contexts. The unusual extent to which Pierre and Henri emphasized their Victorine heritage, as compared to other theologians from the regular clergy, is a reflection of their pride, but not intellectual servitude. Indeed, even if no further discoveries are made, the surviving writings in philosophical theology from four Victorine masters of theology from the long fourteenth century (including Jean) should be considered a success, even if they are preserved in single manuscripts. Over a thousand scholars lectured on the Sentences at the University of Paris from Gérard's year as Sententiarius to the end of the Great Schism, and probably close to a thousand were made master of theology. Less than ten of them were Victorines, and yet about half of the Victorines left pertinent writings that have survived down to the present day. If the Victorine rate applied to all Parisian theologians, we would have similar works from five hundred Parisian bachelors and masters of theology in this period, but this is far from the case. Perhaps only the Franciscans and Dominicans, with their huge international school

\footnotetext{
${ }^{54}$ JeAn Gerson, Euvres complètes, ed. Palémon GlorieuX, t. 2, Paris, 1961 p. 33: « Ad primum juvant, exempli gratia, quaestiones super Sententias et praesertim illorum doctorum qui purius ac solidius conscripserunt, inter quales, meo judicio, dominus Bonaventura et sanctus Thomas et Durandus videtur numerandi ». An older edition of this recommendation with almost the same wording has instead «dominus Altissiodorensis, Bonaventura et Durandus », with Guillaume d'Auxerre rather than Aquinas.
} 
network and support for book production, can match the ratio of the Victorines. The late-medieval Victorines may not have reached the heights of their twelfth-century luminaries, and they may not have produced academics as famous as the leading mendicants, seculars, or even monks, but they certainly held their own. 